\title{
PENGELOLAAN PUPUK TERPADU DALAM UPAYA MENINGKATKAN HASIL JAGUNG MANIS DAN KESUBURAN LAHAN PADA SISTEM TANAM JAJAR LEGOWO 2:1
}

\author{
INTEGRATED FERTILIZERS MANAGEMENT TO INCREASE THE YIELD OF SWEET CORN \\ AND FERTILITY OF THE LAND ON JAJAR LEGOWO 2:1 PLANTING SYSTEM
}

Yefta Pamandungan, David S. Runtunuwu, Rinny Mamarimbing, dan Jemmy Najoan*)

*)Jurusan Budidaya Pertanian, Fakultas Pertanian Unsrat Manado, 95115

\begin{abstract}
This research aims to study the increase of the yields of sweet corn and soil fertility by applying integrated fertilizers management system in Jajar Legowo 2:1 planting system. The results of this research show that providing the $25 \%$ inorganic fertilizers plus $75 \%$ organic fertilizers as treatment has given better result for the yields of sweet corn than providing $100 \%$ inorganic fertilizers or $100 \%$ organic fertilizers as treatment. Chemical properties of the soil before and after the treatment of fertilizers, it is found out that the contents of $\mathrm{C}$-Organic, $\mathrm{N}$ of soil, and $\mathrm{K}_{2} \mathrm{O}$ of the researched soil are categorized as low to very low. However, it is found out that the available content of $\mathrm{P}_{2} \mathrm{O}_{5}$ has increased by $4.29 \mathrm{ppm}$ through the $25 \%$ inorganic fertilizers plus $75 \%$ organic fertilizers as treatment and has increased by 1.73 ppm through the $100 \%$ organic fertilizers as treatment.
\end{abstract}

Keywords: integrated fertilizer management, sweet corn, jajar legowo

\begin{abstract}
ABSTRAK
Penelitian ini bertujuan untuk mengkaji peningkatan hasil tanaman jagung manis dan peningkatan kesuburan lahan melalui penerapan sistem pengelolaan pupuk terpadu pada sistem tanam jajar legowo 2:1. Hasil penelitian menunjukkan bahwa perlakuan $25 \%$ pupuk anorganik $+75 \%$ pupuk organik memberikan hasil tanaman jagung manis yang lebih baik dibandingkan dengan perlakuan 100\% pupuk anorganik atau perlakuan $100 \%$ pupuk organik. Sifat kimia tanah sebelum dan sesudah perlakuan pemupukan didapati bahwa kandungan $\mathrm{C}$-Organik, $\mathrm{N}$ Tanah, $\mathrm{P}_{2} \mathrm{O}_{5}$ dan $\mathrm{K}_{2} \mathrm{O}$ tersedia pada lahan penelitian tergolong dalam kriteria rendah hingga sangat rendah. Meskipun demikian, didapati bahwa kandungan $\mathrm{P}_{2} \mathrm{O}_{5}$ tersedia meningkat sebesar 4,29 ppm melalui perlakuan $25 \%$ pupuk anorganik $+75 \%$ pupuk organik dan meningkat sebesar $1,73 \mathrm{ppm}$ melalui perlakuan $100 \%$ pupuk organik.

Kata kunci: pengelolaan pupuk terpadu, jagung manis, jajar legowo
\end{abstract}

Eugenia Volume 22 No. 1 Pebruari 2016 


\section{PENDAHULUAN}

Jagung manis (Zea mays saccharata Sturt) atau sweet corn merupakan salah satu komoditas pangan yang semakin populer dan mempunyai prospek penting di Indonesia. Hal ini disebabkan jagung manis memiliki rasa yang lebih manis bila dibandingkan dengan jagung biasa, sehingga banyak dikonsumsi oleh masyarakat. Jagung manis mempunyai biji-biji yang berisi endosperm manis, mengkilap, tembus pandang sebelum masak dan berkerut bila kering. Selain itu, umur produksi jagung manis lebih singkat dibandingkan jagung biasa sehingga lebih menguntungkan bila diusahakan.

Kebutuhan jagung manis oleh masyarakat di daerah Manado dan sekitarnya tergolong cukup tinggi. Bagi para pedagang kuliner milu bakar di sepanjang jalan lingkar Manado, kebutuhan jagung manis yaitu sebanyak 15.000 tongkol per hari (Rompis, 2014). Selain itu, jagung manis juga dikonsumsi dalam bentuk jagung muda sebagai milu rebus dan perkedel milu.

Rasa manis pada biji jagung manis disebabkan oleh tingginya kadar gula pada endosperm biji yang berkisar 10-13,8\% sedangkan kadar gula jagung biasa hanya 1-3\% (Palungkun dan Budiarti, 2004; Suarni dan Widowati, 2007). Sifat rasa manis pada biji jagung manis dikendalikan secara genetik. Menurut Lertrat dan Pulam (2007), sifat manis pada jagung disebabkan oleh empat gen resesif yaitu gen resesif su-1 (sugary), bt-1 (brittle), sh-2 (shrunken) dan se-1 (sugary enhancer). Gen ini dapat mencegah perubahan gula menjadi zat pati pada endosperma sehingga jumlah gula yang ada kira-kira dua kali lebih banyak dari jagung biasa.

Secara Nasional, produktivitas jagung dalam kurun waktu tahun 2010-2013 mengalami peningkatan sebesar $0,41 \%$ dari 4,44 ton/ha menjadi 4,84 ton/ha. Produktivitas jagung di Sulawesi Utara sejak tahun 2010-2013 juga mengalami peningkatan sebesar $0,16 \%$ dari 3,65 ton/ha menjadi 3,66 ton/ha (Anonim, 2014). Peningkatan produktivitas jagung tersebut kemungkinan disebabkan oleh penerapan teknologi budidaya tanaman jagung, salah satunya adalah teknologi pemupukan (Soemantri dan Tohari, 2001).

Salah satu permasalahan yang terjadi dibalik keberhasilan peningkatan produktivitas komoditas pertanian di Indonesia termasuk jagung manis yaitu penggunaan pupuk anorganik secara berlebihan. Sebagian besar petani di Indonesia masih banyak menggunakan pupuk anorganik. Hal ini dikarenakan pada penggunaannya yang praktis dan hasil panen yang dinilai memuaskan (Simamora, dkk., 2006). Namun, penggunaan pupuk anorganik dengan dosis yang berlebihan dapat menyebabkan pencemaran lingkungan apalagi kalau penggunaannya secara terus-menerus dalam waktu lama akan berdampak pada penurunan produktivitas lahan.

Permasalahan lainnya adalah ketersediaan pupuk anorganik di pasar sering menjadi kendala bagi petani. Pendistribusian yang tidak tepat waktu dan harga bahan baku yang relatif mahal mengakibatkan harga pupuk anorganik juga relatif mahal. Ketersediaan jenis pupuk anorganik (subsidi) jenis SP-36, Urea dan Phonska pada waktu-waktu tertentu mengalami kelangkaan, sehingga harga pupuk di pasaran melonjak naik. Upaya alternatif untuk mengatasinya yaitu dengan menggunakan pupuk organik (Simamora, dkk., 2006).

Menurut Sutanto (2002) keuntungan yang diperoleh dari penggunaan pupuk organik selain meningkatkan produksi tanaman juga dapat memperbaiki sifat fisik, kimia dan biologi tanah. Pemberian kompos dalam jangka panjang dapat meningkatkan kandungan $\mathrm{N}, \mathrm{P}, \mathrm{K}$ dan $\mathrm{Si}$, meningkatkan aktivitas mikrobia penyemat nitrogen melalui peningkatan kandungan bahan organik tanah yang mudah terdekomposisi, meningkatkan pembentukan agregat yang stabil dan kapasitas pertukaran kation. Keadaan ini besar pengaruhnya pada porositas, penyimpanan dan penyediaan air, aerasi tanah dan suhu tanah (Suriadikarta dan Simanungkalit, 2012).

Meskipun demikian, masih terdapat kelemahan dalam penerapan pupuk organik, diantaranya ialah jumlah pupuk organik diperlukan dalam jumlah yang banyak untuk memenuhi kebutuhan unsur hara tanaman (Sutanto, 2002). Pupuk or- 
ganik yang ditambahkan ke dalam tanah akan mengalami beberapa kali fase dekomposisi oleh mikroorganisme tanah sehingga membutuhkan waktu untuk menjadi bahan organik tanah (Suriadikarta dan Simanungkalit, 2012). Kecepatan dekomposisi menjadi bahan organik tergantung dari suhu, lengas, udara, bahan kimia dan mikroorganisme tanah. Jadi, penggunaan pupuk organik saja tidak dapat meningkatkan produksi tanaman dan kesuburan lahan.

Pengelolaan pupuk terpadu merupakan sebuah sistem yang mengkombinasikan penggunaan pupuk organik dan pupuk anorganik dalam rangka meningkatkan produktivitas lahan dan kelestarian lingkungan. Pupuk anorganik yang diberikan haruslah dalam jumlah yang tidak menekan pertumbuhan mikroorganisme tanah dan pupuk organik yang diberikan haruslah dalam jumlah yang cukup. Kombinasi kedua jenis pupuk tersebut dapat meningkatkan efisiensi penggunaan pupuk anorganik. Hanya dengan cara ini keberlanjutan produksi tanaman dan kelestarian lingkungan dapat dipertahankan. Sistem pertanian yang disebut sebagai LEISA (Low External Input and Sustainable Agriculture) menggunakan kombinasi pupuk organik dan anorganik yang berdasarkan konsep good agricultural practices perlu dilakukan agar degradasi lahan dapat dikurangi.

Selain teknologi pemupukan, penerapan sistem tanam yang tepat seperti jajar legowo 2:1 juga diperlukan untuk meningkatkan produksi tanaman jagung manis (Soemantri dan Tohari, 2001). Sistem tanam jajar legowo 2:1 merupakan komponen teknologi pengaturan jarak tanam dimana penanaman dilakukan dengan jarak tanam sempit dan diikuti dengan jarak tanam lebar. Sistem ini sangat diperlukan untuk mendapatkan tingkat populasi yang optimal, mempermudah dalam perawatan, mendapatkan tambahan pakan (pada sistem relay planting), mengurangi kompetisi mendapatkan unsur hara antar tanaman, serta memaksimalkan penerimaan sinar matahari ke tanaman sehingga sehingga proses fotosintesis dapat berlangsung dengan maksimal. Melalui sistem tanam ini, penerimaan sinar matahari yang optimal oleh tanah juga dapat membantu proses dekomposisi bahan organik tanah. Semakin tinggi suhu hingga mencapai $40^{\circ} \mathrm{C}$ akan semakin mempercepat proses dekomposisi.

Penelitian mengenai pengelolaan pupuk terpadu pada tanaman jagung manis yang menggunakan sistem tanam jajar legowo 2:1 belum banyak dilakukan. Dengan demikian, penelitian ini bertujuan untuk mengkaji peningkatan hasil tanaman jagung manis dan peningkatan kesuburan lahan melalui penerapan sistem pengelolaan pupuk terpadu pada sistem tanam jajar legowo 2:1.

\section{METODE PENELITIAN}

Penelitian dilaksanakan di Desa Kalasey, Kecamatan Mandolang, Kabupaten Minahasa sejak Bulan Mei sampai dengan Bulan September 2015 dan di Laboratorium Kimia dan Kesuburan Lahan, Fakultas Pertanian Unsrat selama Bulan Oktober 2015. Bahan-bahan yang digunakan dalam penelitian ini yaitu benih jagung manis varietas Bonanza F1, pupuk organik cair (POC), kompos, pupuk NPK anorganik dan Urea. Alat-alat yang digunakan yaitu hand tractor, cangkul, garu, meteran, tugal, timbangan analitik, sprayer volume 15 liter, jangka sorong, alat tulis-menulis dan kamera.

Penelitian ini menggunakan Rancangan Acak Kelompok (RAK) dengan 5 perlakuan. Setiap perlakuan terdiri dari 4 ulangan sehingga terdapat 20 unit percobaan. Perlakuan yang dicobakan, yaitu: $P_{1}: 100 \%$ pupuk anorganik yaitu NPK 300 $\mathrm{kg} / \mathrm{ha}$ dan Urea $300 \mathrm{~kg} / \mathrm{ha}$ (dosis anjuran); $\mathrm{P}_{2}: 75 \%$ pupuk anorganik (NPK $225 \mathrm{~kg} / \mathrm{ha}$ dan Urea 225 $\mathrm{kg} / \mathrm{ha}$ ) $+25 \%$ pupuk organik yaitu POC $0,5 \mathrm{l} / \mathrm{ha}$ dan kompos 2,5 t/ha; $\mathrm{P}_{3}: 50 \%$ pupuk anorganik (NPK $150 \mathrm{~kg} / \mathrm{ha}$ dan Urea $150 \mathrm{~kg} / \mathrm{ha})+50 \%$ pupuk organik yaitu POC 1 l/ha dan kompos 5 t/ha; $\mathrm{P}_{4}$ : $25 \%$ pupuk anorganik (NPK $75 \mathrm{~kg} / \mathrm{ha}$ dan Urea 75 $\mathrm{kg} / \mathrm{ha})+75 \%$ pupuk organik yaitu POC $1,5 \mathrm{l} / \mathrm{ha}$ dan kompos 7,5 tha; $P_{5}$ : $100 \%$ pupuk organik yaitu Pupuk Oganik Cair (POC) 2 I/ha dan kompos 10 tha (dosis anjuran)

Variabel yang diamati dalam penelitian ini meliputi : a) sifat kimia tanah sebelum dan sesudah perlakuan pemupukan meliputi $\mathrm{pH} \mathrm{H}_{2} \mathrm{O}, \mathrm{C}-\mathrm{Org}(\%)$, $\mathrm{N}$-Tanah (\%), $\mathrm{P}_{2} \mathrm{O}_{5}$ tersedia (ppm) dan $\mathrm{K}_{2} \mathrm{O}(\mathrm{ppm})$. Sampel tanah yang diperoleh dari lokasi penelitian selanjutnya dilakukan analisis kimia tanah di 
Laboratorium Kimia dan Kesuburan Lahan, Fakultas Pertanian Unsrat; b) hasil jagung manis, yaitu : 1) Berat tongkol berkelobot (g), 2) Berat tongkol tanpa kelobot (g), 3) Panjang tongkol tanpa kelobot $(\mathrm{cm}), 3)$ Diameter tongkol tanpa kelobot (cm) dan 4) Jumlah baris bij/tongkol. Data hasil pengamatan selanjutnya dianalisis menggunakan Analysis of Varians (Anova) untuk melihat pengaruh perlakuan. Bila perlakuan menunjukkan pengaruh nyata maka analisis dilanjutkan dengan menggunakan uji Beda Nyata Terkecil (BNT) pada taraf $5 \%$ $\left(\mathrm{BNT}_{0,05}\right.$ ).

Pelaksanaan penelitian dimulai dengan kegiatan pengolahan tanah menggunakan handtractor sebanyak dua kali dengan kedalaman $20-30 \mathrm{~cm}$ selanjutnya tanah digemburkan dan diratakan menggunakan cangkul serta dibersihkan dari sisa-sisa rumput. Lahan yang tersedia dibuat petakan berukuran $4 \mathrm{~m} \times 2 \mathrm{~m}$ sebanyak 20 petakan. Jarak antar petak perlakuan adalah 200 $\mathrm{cm}$ dan jarak antar ulangan $200 \mathrm{~cm}$. Penanaman benih dilakukan dengan cara membuat lubang tanam sedalam $5 \mathrm{~cm}$ selanjutnya benih ditanam menggunakan sistem tanam legowo 2:1 yaitu setiap 2 baris tanaman dengan jarak tanam $50 \mathrm{~cm} \times 20$ $\mathrm{cm}$ selanjutnya dikosongkan 1 baris tanaman dengan jarak $100 \mathrm{~cm}$ sampai pada baris tanaman berikutnya. Setiap lubang tanam diisi 1-2 selanjutnya dalam pertumbuhannya dijarangkan menjadi 1 tanaman per lubang tanam sehingga dalam setiap petakan terdapat 60 tanaman. Pemupukan tanaman dilakukan sesuai dengan perlakuan pada metode penelitian. Pemberian pupuk NPK dan Urea mengacu pada anjuran umum pemupukan berimbang yaitu NPK $300 \mathrm{~kg} / \mathrm{ha}$ dan Urea $300 \mathrm{~kg} / \mathrm{ha}$ (Anonim, 2011), pupuk kompos 10 tha dan Pupuk Organik Cair (POC) mengacu pada anjuran yang tertera pada kemasan POC 2 I/ha. Pemberian pupuk kompos di petakan dilakukan pada saat 1 minggu sebelum penanaman, pemupukan Urea dan NPK dilakukan secara larikan dengan jarak sekitar $10 \mathrm{~cm}$ dari tanaman dengan kedalaman sekitar $5 \mathrm{~cm}$. Pemupukan Urea dilakukan sebanyak tiga kali pada saat tanaman berumur 0 hst, 21 hst dan 35 hst sedangkan pemupukan NPK dilakukan sebanyak 2 kali pada saat 0 hst dan 21 hst. Penyemprotan POC dilakukan pada saat tanaman berumur 42 hst dan 56 hst. Pengairan dan penyiraman tanaman dilakukan secukupnya hingga tanah menjadi lembab yang bertujuan menjaga agar tanaman tidak layu. Menjelang tanaman berbunga, volume air yang diperlukan lebih lebih banyak sehingga air perlu dialirkan pada parit-parit di antara bumbunan tanaman jagung. Penyiangan dilakukan sebanyak 2-3 kali selama masa pertumbuhan tanaman jagung manis yaitu penyiangan pertama pada umur 14-20 hst dengan cangkul bersamaan dengan pembumbunan dan penyiangan kedua dan ketiga dilakukan tergantung pada perkembangan gulma. Tanaman juga dijaga dari serangan hama dan penyakit. Apabila jumlah serangan masih sedikit $(<5 \%)$ maka dilakukan handpicking, tetapi apabila serangan telah mencapai $>5 \%$ maka dilakukan penyemprotan dengan insektisida atau fungisida. Pemanenan jagung manis dilakukan pada umur 70 hst pada saat biji jagung manis telah masak susu.

\section{HASIL DAN PEMBAHASAN}

\section{Berat Tongkol Jagung Manis dengan Kelobot}

Perlakuan pemupukan berupa pupuk anorganik, kombinasi pupuk anorganik dan organik serta pupuk organik pada tanaman jagung manis memberikan pengaruh tidak nyata terhadap berat tongkol jagung manis dengan kelobot. Rata-rata tertinggi berat tongkol dengan kelobot diperoleh dari perlakuan P4 (25\% pupuk anorganik $+75 \%$ pupuk organik) yaitu sebesar $402,70 \mathrm{~g}$ namun tidak berbeda nyata dengan rata-rata terendah berat tongkol dengan kelobot diperoleh dari perlakuan P2 (75\% pupuk anorganik $+25 \%$ pupuk organik) yaitu $379,60 \mathrm{~g}$ (Tabel 1).

\section{Berat Tongkol Jagung Manis tanpa Kelobot}

Perlakuan pemupukan berupa pupuk anorganik, kombinasi pupuk anorganik dan organik serta pupuk organik pada tanaman jagung manis memberikan pengaruh tidak nyata terhadap berat tongkol tanpa kelobot. Rata-rata tertinggi berat tongkol tanpa kelobot diperoleh dari perlakuan P4 ( $25 \%$ pupuk anorganik $+75 \%$ pupuk organik) yaitu 299,07 g namun tidak berbeda nyata dengan ratarata terendah berat tongkol dengan kelobot yang 
diperoleh dari perlakuan P5 (100\% pupuk organik) yaitu 280,38 g (Tabel 2).

\section{Panjang Tongkol Jagung Manis tanpa Kelobot}

Perlakuan pemupukan berupa pupuk anorganik, kombinasi pupuk anorganik dan organik serta pupuk organik pada tanaman jagung manis memberikan pengaruh tidak nyata terhadap panjang tongkol jagung manis tanpa kelobot. Perlakuan P4 (25\% pupuk anorganik $+75 \%$ pupuk organik) memberikan rata-rata panjang tongkol tertinggi yaitu 21,97 cm namun tidak berbeda nyata dengan perlakuan P3 (50\% pupuk anorganik $+50 \%$ pupuk organik) yang menghasilkan rata-rata panjang tongkol terendah yaitu $21,25 \mathrm{~cm}$ (Tabel 3).

\section{Diameter Tongkol tanpa Kelobot}

Perlakuan pemupukan berupa pupuk anorganik, kombinasi pupuk anorganik dan organik pupuk organik pada tanaman jagung manis memberikan pengaruh tidak nyata terhadap rata-rata diameter tongkol jagung manis. Perlakuan P4 (75\% pupuk anorganik $+25 \%$ pupuk organik) meng- hasilkan diameter tongkol jagung tertinggi yaitu $4,94 \mathrm{~cm}$ namun tidak berbeda nyata dengan perlakuan P5 (100\% pupuk organik) yang menghasilkan diameter tongkol jagung manis terendah yaitu $4,77 \mathrm{~cm}$ (Tabel 4).

\section{Jumlah Baris Biji per Tongkol}

Perlakuan pemupukan berupa pupuk anorganik, kombinasi pupuk anorganik dan organik pupuk organik pada tanaman jagung manis memberikan pengaruh nyata terhadap rata-rata jumlah baris biji per tongkol jagung manis. Perlakuan pemupukan P4 (75\% pupuk anorganik $+25 \%$ pupuk organik) menghasilkan rata-rata jumlah baris biji per tongkol jagung manis tertinggi yaitu 17,33 baris namun tidak berbeda nyata dengan perlakuan $\mathrm{P} 1$ (100\% pupuk anorganik), P2 (75\% pupuk anorganik $+25 \%$ pupuk organik) dan P3 (50\% pupuk anorganik $+50 \%$ pupuk organik), sebaliknya berbeda nyata dengan perlakuan P5 (100\% pupuk organik) yang menghasilkan jumlah baris biji jagung manis terendah yaitu 16,42 baris (Tabel 5).

Tabel 1. Pengaruh Perlakuan Pemupukan terhadap Rata-rata Berat Tongkol Jagung Manis dengan Kelobot (Table 1 Fertilizers Treatment Effect on Average Weight of Sweet Corn Ear With Husk)

\begin{tabular}{lc}
\hline \multicolumn{1}{c}{ Perlakuan } & Rata-rata Berat Tongkol dengan Kelobot (g) \\
\hline P1 (100\% pupuk anorganik) & 390,09 \\
P2 (75\% pupuk anorganik + 25\% pupuk organik) & 379,60 \\
P3 (50\% pupuk anorganik + 50\% pupuk organik) & 381,32 \\
P4 (25\% pupuk anorganik + 75\% pupuk organik) & 402,70 \\
P5 (100\% pupuk organik) & 395,38 \\
\hline
\end{tabular}

Tabel 2. Pengaruh Perlakuan Pemupukan terhadap Rata-rata Berat Tongkol Jagung Manis tanpa Kelobot (Table 2. Fertilizers Treatment Effect on Average Weight of Sweet Corn Ear Without Husk)

\begin{tabular}{lc}
\hline \multicolumn{1}{c}{ Perlakuan } & Rata-rata Berat Tongkol tanpa Kelobot $(\mathrm{g})$ \\
\hline P1 (100\% pupuk anorganik) & 296,68 \\
P2 (75\% pupuk anorganik + 25\% pupuk organik) & 297,50 \\
P3 (50\% pupuk anorganik + 50\% pupuk organik) & 280,41 \\
P4 (25\% pupuk anorganik + 75\% pupuk organik) & 299,07 \\
P5 (100\% pupuk organik) & 280,38 \\
\hline
\end{tabular}


Tabel 3. Pengaruh Perlakuan Pemupukan terhadap Rata-rata Panjang Tongkol Jagung Manis tanpa Kelobot (Table 3. Fertilizers Treatment Effect on Average Lenght of Sweet Corn Ear Without Husk)

\begin{tabular}{lc}
\hline \multicolumn{1}{c}{ Perlakuan } & Rata-rata Panjang Tongkol tanpa Kelobot $(\mathrm{cm})$ \\
\hline P1 (100\% pupuk anorganik) & 21,59 \\
P2 (75\% pupuk anorganik + 25\% pupuk organik) & 21,90 \\
P3 (50\% pupuk anorganik + 50\% pupuk organik) & 21,25 \\
P4 (25\% pupuk anorganik + 75\% pupuk organik) & 21,97 \\
P5 (100\% pupuk organik) & 21,31 \\
\hline
\end{tabular}

Tabel 4. Pengaruh Perlakuan Pemupukan terhadap Rata-rata Diameter Tongkol Jagung Manis

(Table 4. Fertilizers Treatment Effect on Average Diameter of Sweet Corn Ear)

\begin{tabular}{lc}
\hline \multicolumn{1}{c}{ Perlakuan } & Rata-rata Diameter Tongkol $(\mathrm{cm})$ \\
\hline P1 (100\% pupuk anorganik) & 4,90 \\
P2 (75\% pupuk anorganik + 25\% pupuk organik) & 4,91 \\
P3 (50\% pupuk anorganik + 50\% pupuk organik) & 4,90 \\
P4 (25\% pupuk anorganik + 75\% pupuk organik) & 4,94 \\
P5 (100\% pupuk organik) & 4,77 \\
\hline
\end{tabular}

Tabel 5. Pengaruh Perlakuan Pemupukan terhadap Rata-rata Jumlah Baris Biji per Tongkol Jagung Manis (Table 5. Fertilizers Treatment Effect on Average Number of Sweet Corn Seed Rows)

\begin{tabular}{lc}
\hline \multicolumn{1}{c}{ Perlakuan } & Rata-rata Jumlah Baris per Tongkol \\
\hline P1 (100\% pupuk anorganik) & $17,08^{\mathrm{ab}}$ \\
P2 (75\% pupuk anorganik + 25\% pupuk organik) & $17,25^{\mathrm{ab}}$ \\
P3 (50\% pupuk anorganik + 50\% pupuk organik) & $16,92^{\mathrm{ab}}$ \\
P4 (25\% pupuk anorganik + 75\% pupuk organik) & $17,33^{\mathrm{a}}$ \\
P5 (100\% pupuk organik) & $16,42^{\mathrm{b}}$ \\
\hline Keterangan: Angka yang diikuti oleh huruf yang sama pada kolom yang sama menunjukkan tidak berbeda nyata \\
berdasarkan uji BNT pada taraf 5\%
\end{tabular}

\section{Analisis Sifat Kimia Tanah}

Berdasarkan hasil analisis sifat kimia tanah sebelum dan sesudah perlakuan pemupukan didapati bahwa kandungan C-Organik dan $\mathrm{N}$ Tanah, $\mathrm{P}_{2} \mathrm{O}_{5}$ dan $\mathrm{K}_{2} \mathrm{O}$ tersedia pada lahan penelitian tergolong dalam kriteria rendah hingga sangat rendah. Meskipun demikian, didapati bahwa kandungan $\mathrm{P}_{2} \mathrm{O}_{5}$ tersedia meningkat sebesar 4,29 ppm melalui perlakuan P4 dan meningkat sebesar 1,73 ppm melalui perlakuan P5 (Tabel 6).

Perlakuan pemupukan berupa pupuk anorganik, kombinasi pupuk anorganik dan organik serta pupuk organik pada tanaman jagung manis memberikan pengaruh tidak nyata terhadap ratarata berat tongkol dengan kelobot, berat tongkol tanpa kelobot, panjang tongkol dan diameter tongkol namun memberikan pengaruh nyata terhadap rata-rata jumlah baris biji jagung manis. Hasil pengamatan menunjukkan bahwa perlakuan P4 ( $25 \%$ pupuk anorganik $+75 \%$ pupuk organik) memberikan hasil tanaman jagung manis yang tidak berbeda nyata dengan perlakuan pupuk anorganik rekomendasi yaitu P1 (100\% anorganik) sekaligus tertinggi dibandingkan dengan perlakuan lainnya yaitu P1, P2, P3 dan P5. Rata-rata berat tongkol dengan kelobot dan tanpa kelobot masing-masing 402,70 g dan 299,07 g dengan perlakuan P4 pada penelitian ini lebih tinggi dibandingkan dengan hasil penelitian Hayati, $d k k$. (2011) yaitu $175,18 \mathrm{~g}$ dan $162,76 \mathrm{~g}$ melalui perlakuan pemupukan $50 \%$ anorganik dan $50 \%$ organik. 
Tingginya hasil tanaman jagung yang diperoleh dari perlakuan P4 (25\% pupuk anorganik + $75 \%$ pupuk organik) disebabkan oleh ketersediaan unsur hara yang cukup untuk mendukung pertumbuhan tanaman dan pengisian biji. Meskipun kandungan unsur hara yang berasal dari pupuk anorganik rendah yaitu hanya $25 \%$ dari dosis rekomendasi (300 kg/ha NPK dan Urea) namun unsur hara yang berasal dari pupuk organik yaitu pupuk kompos dan pupuk organik cair (POC) memiliki peranan sebagai pelengkap (complement). Selain itu, kondisi tanah di lokasi penelitian juga mendukung perkembangan perakaran dan proses penyerapan hara.

Hasil tanaman yang dicapai pada perlakuan P5 (100\% pupuk organik) lebih rendah dibandingkan perlakuan P1 (100\% pupuk anorganik) pada komponen berat tongkol tanpa kelobot, panjang tongkol, diameter tongkol dan jumlah baris biji kemungkinan disebabkan oleh pemberian pupuk organik (kompos) sebanyak 10 ton/ha yang belum mencukupi kebutuhan tanaman untuk menunjang pertumbuhan dan hasil, karena tanah kandungan kimia tanah di lokasi penelitian memiliki C-organik yang rendah yaitu $<2 \%$ (Tabel 6). Padahal untuk memperoleh produksi optimal dibutuhkan C-organik $>2,5 \%$. Selain itu, pupuk organik yang ditambahkan ke dalam tanah akan mengalami beberapa kali fase perombakan oleh mikroorganisme tanah untuk menjadi bahan organik tanah, sehingga kesuburan tanah belum mengalami peningkatan dalam jangka pendek (Simamora, dkk., 2006).
Pengelolaan pupuk terpadu dengan cara mengkombinasi penggunaan pupuk anorganik dan organik dengan tujuan meningkatkan produksi tanaman sekaligus kesuburan lahan secara bertahap dapat tercapai. Penambahan bahan organik meskipun berpengaruh tidak nyata terhadap hasil jagung manis, namun memberikan hasil tertinggi dibandingkan dengan perlakuan P1 (100\% pupuk anorganik). Hasil pengamatan yang diperoleh menunjukkan bahwa penggunaan kombinasi pupuk anorganik dan organik melalui perlakuan P4 (25\% pupuk anorganik $+75 \%$ pupuk organik) selain memberikan hasil tertinggi, juga dapat menurunkan pemakaian pupuk anorganik sebanyak $75 \%$ yaitu sebesar $225 \mathrm{~kg} / \mathrm{ha}$ NPK dan $225 \mathrm{~kg} / \mathrm{ha}$ Urea.

Pengaruh tidak nyata semua perlakuan terhadap sebagian besar komponen hasil tanaman jagung manis juga dapat disebabkan oleh penerapan sistem tanam jajar legowo 2:1. Penerapan sistem tanam ini memiliki salah satu keuntungan yaitu meningkatkan penerimaan intensitas cahaya matahari pada daun sehingga hasil asimilat meningkat akibatnya pengisian biji dapat optimal. Srihartanto dkk (2013) menjelaskan bahwa sistem tanam jajar legowo 2:1 terbukti dapat meningkatkan produktivitas jagung, mempermudah dalam perawatan, mengurangi kompetisi mendapatkan unsur hara antar tanaman serta memaksimalkan penerimaan sinar matahari ke tanaman sehingga proses fotosintesis dapat maksimal.

Tabel 6. Sifat Kimia Tanah Sebelum dan Sesudah Perlakuan Pemupukan

(Table 6. Chemical Properties of Soil Before and After Fertilizers Treatment)

\begin{tabular}{|c|c|c|c|c|c|}
\hline \multirow[b]{2}{*}{ Perlakuan } & \multicolumn{5}{|c|}{ Sifat Kimia Tanah } \\
\hline & $\mathrm{pH} \mathrm{H} \mathrm{H}_{2} \mathrm{O}$ & $\begin{array}{c}\text { C-org } \\
(\%)\end{array}$ & $\begin{array}{c}\text { N-Tanah } \\
(\%)\end{array}$ & $\begin{array}{c}\mathrm{P}_{2} \mathrm{O}_{5} \\
\text { tersedia } \\
(\mathrm{ppm})\end{array}$ & $\begin{array}{l}\mathrm{K}_{2} \mathrm{O} \\
\text { (ppm) }\end{array}$ \\
\hline Sebelum perlakuan pemupukan & 6,50 & 1,83 & 0,15 & 10,45 & 14,07 \\
\hline P1 (100\% pupuk anorganik) & 6,43 & 1,34 & 0,11 & 11,67 & 6,34 \\
\hline P2 (75\% pupuk anorganik + 25\% pupuk organik) & 6,38 & 1,71 & 0,13 & 11,24 & 10,78 \\
\hline P3 (50\% pupuk anorganik + 50\% pupuk organik) & 6,35 & 1,22 & 0,10 & 8,99 & 5,95 \\
\hline P4 (25\% pupuk anorganik $+75 \%$ pupuk organik) & 6,38 & 0,98 & 0,09 & 14,74 & 6,73 \\
\hline P5 (100\% pupuk organik) & 6,36 & 1,53 & 0,14 & 12,18 & 9,62 \\
\hline
\end{tabular}




\section{KESIMPULAN DAN SARAN}

\section{Kesimpulan}

Penerapan sistem pengelolaan pupuk terpadu pada sistem tanam jajar legowo 2:1 melalui perlakuan $25 \%$ pupuk anorganik (NPK $75 \mathrm{~kg} \mathrm{ha}^{-1}$ dan Urea $75 \mathrm{~kg} / \mathrm{ha}$ ) $+75 \%$ pupuk organik (POC 1,5 I/ha dan kompos 7,5 t/ha) dapat meningkatkan hasil tanaman jagung manis pada komponen berat tongkol dengan kelobot, berat tongkol tanpa kelobot, panjang tongkol, diameter tongkol dan jumlah baris biji yang lebih tinggi dibandingkan dengan perlakuan $100 \%$ pupuk anorganik dan perlakuan $100 \%$ pupuk organik. Penerapan sistem ini juga meningkatkan kesuburan lahan melalui peningkatan kandungan kimia tanah yaitu kandungan $\mathrm{P}_{2} \mathrm{O}_{5}$ tersedia meningkat sebesar 4,29 ppm melalui perlakuan pemupukan $25 \%$ pupuk anorganik (NPK 75 $\mathrm{kg} \mathrm{ha}^{-1}$ dan Urea $\left.75 \mathrm{~kg} / \mathrm{ha}\right)+75 \%$ pupuk organik (POC 1,5 l/ha dan kompos 7,5 t/ha).

\section{Saran}

Untuk meningkatkan hasil jagung manis disarankan untuk menggunakan dosis dan konsentrasi pemupukan $25 \%$ pupuk anorganik (NPK 75 $\mathrm{kg} \mathrm{ha}^{-1}$ dan Urea $75 \mathrm{~kg} / \mathrm{ha}$ ) $+75 \%$ pupuk organik (POC 1,5 I/ha dan kompos 7,5 t/ha).

Untuk meningkatkan kesuburan lahan pertanaman jagung manis disarankan untuk meningkatkan dosis anjuran pupuk organik berupa kompos menjadi 15-20 tha mengingat kandungan kimia tanah sebelum perlakuan pemupukan masih tergolong rendah hingga sangat rendah.

\section{UCAPAN TERIMA KASIH}

Penulis mengucapkan terima kasih kepada Lembaga Penelitian dan Pengabdian kepada Masyarakat (LPPM) Unsrat yang telah memberikan kesempatan untuk melaksanakan Riset Unggulan Universitas (RUU) yang dibiayai dari DIPA Unsrat tahun 2015.

\section{DAFTAR PUSTAKA}

Anonim. 2011. Anjuran Umum Pemupukan Berimbang Menggunakan Pupuk Majemuk. http://petrokimia-gresik.com. Diakses tanggal 8 September 2014.

Anonim. 2014. Luas Panen Produktivitas Produksi Tanaman Jagung Provinsi Indonesia. http://bps.go.id. Diakses tanggal 31 Agustus 2014.

Hayati, M., E. Hayati, dan D. Nurfandi. 2011. Pengaruh Pupuk Organik dan Anorganik Terhadap Pertumbuhan Beberapa Varietas Jagung Manis di Lahan Tsunami. Jurnal Floratek 6:74-83. http://jurnal. unsyiah.ac.id. Diakses Tanggal 1 September 2014.

Lertrat, K. and T. Pulam. 2007. Breeding for Increased Sweetness in Sweet Corn. International Jurnal of Plant Breeding. Vol. 1, No. 1, p. 27-30. Thailand. http://www. globalsciencebooks.info. Diakses tanggal 7 September 2014.

Palungkun, R., dan A. Budiarti. 2004. Sweet Corn Baby Corn. Penebar Swadaya. Jakarta. 80 hlm.

Rompis, A. 2014. Jagung Suwaan Laris di Ring Road. http://manado.tribunnews.com. 8 Januari 2014. Diakses tanggal 8 September 2014.

Simamora, Suhud, dan Salundik. 2006. Meningkatkan Kualitas Kompos. Agro Media Pustaka. Jakarta.

Soemantri, S. dan Tohari. 2001. Pengelolaan Lahan Sawah Tadah Hujan Untuk Berkelanjutan Sistem Produksi. Prosiding Seminar Nasional Budidaya Tanaman Pangan Berwawasan Lingkungan. Puslitbang Tanaman Pangan. Bogor.

Srihartanto, E., S.W. Budiarti dan Suwarti. 2013. Penerapan Sistem Tanam Jajar Legowo Jagung Hibrida Untuk Peningkatan Produktivitas Di Lahan Inceptisols 
Gunungkidul. Seminar Nasional Serealia Tahun 2013. http://balitsereal.litbang. deptan.go.id. Diakses tanggal 31 Agustus 2014.

Suarni dan S. Widowati. 2007. Struktur, Komposisi, dan Nutrisi Jagung. Prosiding Jagung: Teknik Produksi dan Pengembangan. HIm.410-426. Balai Penelitian Tanaman Serealia. Maros.
Suriadikarta, D.A., dan R.D.M. Simanungkalit, 2012. Pendahuluan. Prosiding Pupuk Organik dan Pupuk Hayati. Badan Penelitian dan Pengembangan Pertanian, Kementrian Pertanian. Bogor.

Sutanto, R. 2002. Penerapan Pertanian Organik: Pemasyarakatan dan Pengembangannya. Kanisius. Yogyakarta. 